\title{
EFEKTIVITAS PELATIHAN MANAJEMEN RESIKO DALAM UPAYA PENINGKATAN PENGETAHUAN, SIKAP DAN KETRAMPILAN PENDERES
}

\author{
THE EFFECTIVENESS OF RISK MANAGEMENT TRAINING IN EFFORTS TO \\ IMPROVE KNOWLEDGE, ATTITUDE, AND SKILLS OF FARMER SUGAR
}

\author{
Nur Ulfah, Budi Aji, Siti Harwanti \\ Jurusan Kesehatan Masyarakat Fakultas Ilmu-Ilmu Kesehatan \\ Universitas Jenderal Soedirman
}

\begin{abstract}
Banyumas is one of the centers of the head sugar industry. Around 27 thousand family heads $(\mathrm{KK})$ depend their lives to process palm water into coconut sugar. The number of work accidents, the roomie juice in Banyumas is very high. The risk as a roomie is not only death but also permanent disability. In 2016 there were 126 fallers, 52 of whom died and 74 suffered disabilities. In 2017, until October there were 138 residents who fell, 53 died and 85 disabled. The purpose of this study is to improve the knowledge, attitudes and skills of coconut dwellers about work accident risk management. The method used in this study is an experimental method, sampling using a purposive sampling method with criteria for a minimum level of education at junior high school and productive age. Data were collected using questionnaire sheets and observation sheets. That there are differences in the knowledge of respondents before and after training with an increase in knowledge of $15.91 \%$, there are differences in the attitudes of respondents before and after training with an increase in attitude of $4.89 \%$, and there are differences in the skills of respondents before and after mentoring with a $50 \%$ increase in skills. The process of training and mentoring activities should be able to be followed up further by the village in order to change the behavior of the inhabitants to safe behavior which requires a short amount of time, and the need for a study related to the unsafe condition and unsafe behavior that caused the accident work with a qualitative approach.
\end{abstract}

Keyword: Training, knowledge, attitudes and skills

\begin{abstract}
ABSTRAK
Banyumas merupakan salah satu sentra industri gula kepala. Sekitar 27 ribu kepala keluarga (KK) menggantungkan hidupnya mengolah air nira menjadi gula kelapa. Angka kecelakaan kerja, para penderes nira di Banyumas sangat tinggi. Risiko sebagai penderes nira, tidak hanya kematian namun juga cacat permanen. Tahun 2016 tercatat ada 126 penderes jatuh, 52 orang diantaranya meninggal dan 74 orang mengalami cacat. Tahun 2017, data sampai Oktober sudah ada 138 penderes terjatuh, 53 meninggal dan 85 cacat. Tujuan penelitian ini adalah untuk meningkatkan pengetahuan, sikap dan keterampilan penderes kelapa tentang manajemen resiko kecelakaan kerja. Metode yang digunakan dalam penelitian ini yaitu metode eksperimen, pengambilan sampel menggunakan metode purposive sampling dengan kriteria tingkat pendidikan minimal SMP dan usia produktif. Data dikumpulkan dengan menggunakan lembar kuesioner dan lembar observasi. Hasilnya terdapat perbedaan pengetahuan responden sebelum dan sesudah pelatihan dengan peningkatan pengetahuan sebesar $15,91 \%$, ada perbedaan sikap responden sebelum dan sesudah pelatihan dengan peningkatan sikap sebesar 4,89\%,dan terdapat perbedaan ketrampilan responden sebelum dan sesudah pendampingan dengan peningkatan keterampilan sebesar 50\%. Proses kegiatan pelatihan dan pendampingan sebaiknya bisa di follow up lebih lanjut oleh pihak desa dengan tujuan untuk merubah perilaku penderes kepada perilaku yang aman membutuhkan waktu yang tidak singkat, serta perlu adanya sebuah penelitian terkait dengan faktor kondisi tidak aman dan perilaku tidak aman yang menyebabkan kejadian kecelakaan kerja dengan pendekatan kualitatif.
\end{abstract}

Keyword : Pelatihan, pengetahuan, sikap dan keterampilan 
PENDAHULUAN

Kecelakaan kerja (accident) menurut Sucipto (2014) adalah kecelakaan yang berhubung dengan hubungan kerja pada perusahaan atau perkantoran. Permenaker No. 609 Tahun 2012, menyatakan bahwa kecelakaan kerja merupakan kejadian tidak disengaja berhubungan dengan hubungan kerja, demikian pula kecelakaan yang terjadi dalam perjalanan berangkat dari rumah menuju tempat kerja dan pulang ke rumah melalui jalan yang biasa atau wajar dilalui.

Berdasarkan hasil penelitian Aji dkk (2015), bahwa di Kecamatan Cilongok khususnya di Desa Pageraji, Langgongsari dan Rancamaya terdapat kecelakaan kerja pada penderes sebanyak 94 orang $(89,5 \%)$, dimana dari 94 orang tersebut sebagian yaitu sebanyak 2 orang $(1,9 \%)$ jatuh dari pohon kelapa, 66 orang $(62,9 \%)$ terpeleset, dan 26 orang $(24,8 \%)$ lainnya tergores dan tersiram air gula panas.

Penelitian Ulfah (2017), khususnya di Desa Rancamaya Kecamatan Cilongok, terdapat kasus penderes terjatuh dari pohon kelapa sebanyak 32 orang $(53,3 \%)$ dari total
60 penderes. Jika kejadian kecelakaan kerja dibiarkan terus menerus, maka dapat mengurangi kapasitas kerja, mengurangi produktifitas, nilai investasi, serta tentu saja derajat kesehatan dari pekerja menurun. Oleh karena itu, diperlukan suatu pelatihan manajemen resiko sebagai upaya mengurangi kejadian kecelakaan kerja pada penderes nira kelapa di Kecamatan Cilongok

Pelatihan manajemen resiko merupakan salah satu pelatihan tentang perilaku aman bekerja yang spesifik menyoroti masalah bagaimana kita melakukan evaluasi diri terhadap kegiatan kerja kita, apakah pekerjaan kita beresiko atau tidak terhadap kecelakaan, sehingga timbul kesadaran bagi penderes untuk selalu berhati-hati dalam bekerja.

Tujuan kegiatan ini adalah untuk meningkatkan pengetahuan dan sikap penderes tentang manajemen resiko kecelakaan kerja serta meningkatkan keterampilan penderes dalam hal identifikasi resiko, penilaian resiko dan pengendalian resiko kecelakaan. 
METODE

Metode yang digunakan dalam penelitian ini yaitu metode eksperimen. Teknik pengambilan sampel menggunakan metode purposive sampling dengan kriteria tingkat pendidikan minimal SMP dan usia produktif dengan jumlah sampel sebanyak 29 responden. Uji statistic yang digunakan yaitu uji Wicoxon untuk megetahui perbedaan keterampilan responden setelah diberikan perlakuan.

\section{HASIL DAN PEMBAHASAN}

$$
\text { Kegiatan pelatihan, }
$$
pendampingan dan keterjangkauan (out reach) dapat berjalan lancar dan sesuai dengan tujuan pengabdian. Kegiatan pelatihan menghasilkan output yaitu peningkatan pengetahuan dan sikap penderes.
Kegiatan

pendampingan

menghasilkan output berupa peningkatan ketrampilan dan buku saku. Sedangkan penjangkauan (outreach) menghasilkan output berupa peningkatan pengetahuan dan sikap penderes.

Adapun kecenderungan peningkatan pengetahuan dan sikap dapat dilihat dalam evaluasi pre dan post tes pelatihan. Berikut adalah hasil evaluasi pre dan post tes pelatihan :

Tabel berikut menunjukkan bahwa adanya perubahan tingkat pengetahuan peserta setelah mendapat pelatihan manajemen resiko, terlihat dari nilai rata-rata pengetahuan yaitu dari 15,58 meningkat menjadi 18,06.

Tabel 1. Gambaran Skor Pengetahuan Kelompok Perlakuan

\begin{tabular}{lccc}
\hline \multicolumn{1}{c}{ Pengetahuan } & Nilai Terendah & Nilai Tertinggi & Rata-Rata \\
\hline Pre Test & 8 & 20 & 15,58 \\
Post Test & 13 & 20 & 18,06 \\
\end{tabular}

Presentase peningkatan dapat dihitung menggunakan rumus pengetahuan sebelum dan sesudah sebagai berikut:

pelatihan pada kelompok perlakuan 
80 Nur Ulfah, Efektivitas Pelatihan Manajemen Resiko Dalam Upaya Peningkatan

Pengetahuan, Sikap Dan Ketrampilan Penderes

$$
\begin{aligned}
& \frac{\text { Mean Post Test }- \text { Mean Pre Test }}{\text { Mean Pre Test }} \times 100 \% \\
& =\frac{18,06-15,58}{15,58} \times 100 \% \\
& =15,91 \%
\end{aligned}
$$

Peningkatan pengetahuan responden

pada kelompok perlakuan adalah sebesar $15,91 \%$.

Sementara itu dilihat dari

hasil evaluasi terhadap sikap peserta

pelatihan, didapatkan hasil sebagai berikut :Tabel 2 menunjukkan bahwa adanya perubahan tingkat sikap pada kelompok perlakuan, terlihat dari nilai rata-rata sikap yaitu dari 64

\begin{tabular}{|c|c|c|c|}
\hline Sikap & Nilai Terendah & Nilai Tertinggi & Rata-Rata \\
\hline Pre Test & 55 & 75 & 64 \\
\hline Post Test & 58 & 80 & 67,13 \\
\hline
\end{tabular}
meningkat menjadi 67,13 .

Tabel 2. Gambaran Skor Sikap Kelompok Perlakuan

Presentase peningkatan sikap kelompok perlakuan dapat dihitung sebelum dan sesudah pelatihan pada menggunakan rumus sebagai berikut:

$\frac{\text { Mean Post Test }- \text { Mean Pre Test }}{\text { Mean Pre Test }} \times 100 \%$

$$
\begin{aligned}
& =\frac{67,13-64}{64} \times 100 \% \\
& =4,89 \%
\end{aligned}
$$

Peningkatan perilaku responden pada evaluasi terhadap pelaksanaan kelompok perlakuan adalah sebesar pendampingan dan penjangkauan. $4,89 \%$. Hasil evaluasi pendampingan Selain evaluasi kegiatan dilakukan dengan observasi. Dari pelatihan, pelaksana juga melakukan hasil pengamatan, terlihat jelas 
bahwa penderes sudah betul betul

faham dengan materi yang disampaikan dan terlihat mahir dalam melakukan evaluasi diri terkait manajemen resiko. Hasil pengamatan terlampir pada dokumentasi kegiatan.Hasil uji normalitas menggunakan uji statistik Wilcoxon bahwa pre test keterampilan Table 3. Skor Keterampilan Responden menunjukkan data konstan, artinya secara statistik menunjukkan bahwa data berdistribusi normal. Sedangkan post test keterampilan memperoleh nilai $\mathrm{p}=0,835<\alpha(0,05)$, artinya secara statistik menunjukkan bahwa data berdistribusi berdistribusi normal, sehingga uji beda yang digunakan yaitu uji Wilcoxon.

\begin{tabular}{ccccc}
\hline Variabel & Nilai Terendah & Nilai Tertinggi & Rata-Rata & Peningkatan \\
Keterampilan & & 0 & 0,00 & \\
\hline Pre Test & 0 & 47 & 39,2 & 39,2 \\
Post Test & 31 & & \\
\hline
\end{tabular}

Hasil anilisis data pada responden pada table 3 menunjukkan bahwa terjadi perubahan peningkatan keterampilan responden. Hal ini dapat dilihat dari rata-rata skor keterampilan pada saat pre test 0,00 Tabel 4. Hasil Uji Beda Keterampilan Sebelum dan Sesudah Pendampingan meningkat menjadi 39,2 pada saat post test. Berdasarkan hasil perhitungan dapat diketahui bahwa peningkatan nilai rata-rata skor keterampilan antara pre test dan post test yaitu sebesar 39,2.

\begin{tabular}{cccccc}
\hline $\begin{array}{c}\text { Skor } \\
\text { Keterampilan }\end{array}$ & $\begin{array}{c}\text { Skor Rata- } \\
\text { Rata }\end{array}$ & $\begin{array}{c}\text { Uji yang } \\
\text { digunakan }\end{array}$ & Nilai $\mathrm{p}$ & Nilai $\alpha$ & Simpulan \\
\hline $\begin{array}{c}\text { Pre Test } \\
\text { Post Test }\end{array}$ & 0,00 & Wilcoxon & 0,00 & 0,05 & $\begin{array}{c}\text { Ada Perbedaan } \\
\text { Keterampilan }\end{array}$ \\
\hline
\end{tabular}

Table 4 menunjukkan bahwa keterampilan responden sebelum dan terdapat peningkatan nilai rata-rata sesudah pendampingan yaitu dari 
0,00 menjadi 39,2. Hasil uji statistik dengan menggunakan uji Wilcoxon diperoleh nilai $\mathrm{p}=0,00<\alpha(0,05)$, artinya secara statistik menunjukkan ada perbedaan keterampilan yang signifikan sebelum dan sesudah pendampingan.

\section{SIMPULAN DAN SARAN}

Simpulan dalam penelitian ini berdasar evaluasi kegiatan pelatihan terdapat peningkatan pengetahuan penderes sebesar 15,91 \% dan peningkatan sikap sebesar 4,89\% Berdasar evaluasi kegiatan pendampingan terdapat perbedaan ketrampilan penderes saat sebelum dan setelah kegiatan pendampingan dengan rata-rata peningkatan sebesar $50 \%$

Saran terkait hasil penelitian ini yaitu proses kegiatan pelatihan dan pendampingan sebaiknya bisa di follow up lebih lanjut oleh pihak desa karena untuk merubah perilaku penderes kepada perilaku yang aman membutuhkan waktu yang tidak singkat. Perlu adanya sebuah penelitian terkait dengan faktor yang menyebabkan kejadian kecelakaan kerja dari aspek sarana dan prasarana ergonomi yang digunakan saat bekerja

\section{DAFTAR PUSTAKA}

Aji, B., Ulfah N., Masfiah S., Harwanti S. 2015. Extending social health protection to informal sector in Indonesia: How to enroll palm sugar farmers in national health insurance. Laporan hasil penelitian International Research Collaboration Grant (IRC UNSOED) tahun 2015. Purwokerto

Badan Pusat Statistik. 2011. Kecelakaan kerja dalam angka. Diakses tanggal 11 Desember 2014

Badan Pusat Statistik. 2015. Data Statistik Kecelakaan Kerja di Indonesia. Diakses tanggal 11 November 2011

Mathis R.L dan Jackson J.H, 2002. Manajemen Sumber Daya Manusia. Jakarta: Salemba Empat.

Notoatmodjo. 2012. Promosi Kesehatan Teori dan Aplikasi. Rineka Cipta. Jakarta

Nurkholis dan Ardyansyah, 2017, Pengendalian Bahaya Kerja Dengan Metode Job Safety Analysis Pada Penerimaan Afval Lokal Bagian Warehouse Di PT. ST, Jurnal Teknika Engineering and Sains, Vol 1(1)

Pusdatinaker. 2012. Tipe Kecelakaan Kerja di Indonesia menurut Provinsi $\underline{\text { Tahun }}$ 2012.(online)http://pusdatinaker.bal itfo.depnakertrans.go.id/viewpdf.ph p?id=289. Diakses tanggal 7 November 2015

Permenkes 432/Menkes/IV/2007. Pedoman Manajemen Resiko di Tempat Kerja. Kemenker RI. 2007. Jakarta

Rosdiana, Anggraeni, Umyati, A. 2017. Identifikasi Risiko Kecelakaan Kerja pada Area Produksi Proyek Jembatan Dengan Metode Job Safety Analysis (JSA). Jurnal Teknik Industri. Vol. 5 No. 1 
Srigito. 2011. Data Kecelakaan Kerja Penderes. Kesra Setda Banyumas dalam Harian Tempo tanggal 19 September 2011

Suara Merdeka. 2013. Angka Kecelakaan Kerja Masih Tinggi. (on-line). www.suaramerdeka.com/v1/index.p hp/read/cetak/2012/07/07/191800/A ngka-Kecelakaan-Kerja-MasihTinggi. Diakses tanggal 11 Maret 2014.
Sucipto, CD. 2014. Keselamatan dan Kesehatan Kerja. CV. Gosyen Publishing. Yogyakarta

Ulfah, 2016. Analisis resiko kecelakaan kerja pada penderes kelapa di Kecamatan Cilongok. Laporan Penelitian Riset Peningkatan Kompetensi. LPPM Unsoed 